\title{
The outbreak of foot-and-mouth disease in Worcestershire
}

\author{
An epidemiological study: with special reference to spread of \\ the disease by wind-carriage of the virus
}

\author{
By R. J. HENDERSON \\ Public Health Laboratory, Worcester
}

(Received 15 May 1968)

\begin{abstract}
During the recent epizootic of foot-and-mouth disease which attacked the country in the winter of $1967 / 8$, Worcestershire was among the affected counties. The area affected is known as Spetchley. The disease appeared in three pig farms on 16, 17 and 18 November 1967 respectively. These farms are owned jointly by two brothers. It is understood that the disease travelled to Worcestershire in a tanker load of skimmed milk and some of the load was distributed equally among the three pig farms. The disease spread out radially from the first of the three pig farms and later from the second until twenty-nine neighbouring farms were involved, and only died out with the infection of the thirty-second farm on 6 December.
\end{abstract}

On a visit to the control centre at Hindlip when the Worcestershire outbreak was nearing its end I was shown a plan which had been prepared by Mr J. S. Needham of the control staff. On it Mr Needham had endeavoured to show that the spread of the infection from the source to the neighbouring farms could, in most cases, have been by wind. The impression of the farmers as repeated to me by Mr Needham seemed to confirm this. I thought that the matter of wind carriage should be looked at closely.

When the outbreak was over therefore and one was free to move about, I paid a visit to each of the farms which had been attacked, learned as much as I could from the farmer himself about the arrival of the disease, discussed the precautions he had taken, and so on. I thought at the time that one or two farmers after a lapse of 8 weeks might perhaps have forgotten the sequence of events. I need not have worried. Each farmer appeared to be absolutely clear about the timing of events, remembering even the smallest detail. The boundaries of each farm were marked on a $2 \frac{1}{2}$ in. to the mile map; inquiries were made about the exact disposition of the animals at the time when I judged the infection had arrived on the farm, and about the direction in which the sheds, barns, and byres faced. When all this was done, I visited the R.A.F. Meteorological Station at Pershore (only a few miles from the outbreak) where hourly records of wind force, wind direction, rainfall, and other climatic conditions are kept. I received the information I required and my conclusions are in the following pages. 


\section{THE PART POSSIBLY PLAYED BY THE WIND}

The infection was first noticed at one of the pig farms (black square on Fig. 1) on 15 November (lameness and raised temperature in two sows and two piglets). The diagnosis was confirmed on 16 November and two more piglets were then seen to be infected. The infected animals were slaughtered on 16 November and the remaining stock slaughtered and buried by $21.00 \mathrm{hr}$. on 17 November. Maximum spread of infection from this farm was likely therefore on 15,16 and 17 November. Was it possible that the infection was spread to neighbouring farms on the wind? It seems that this could happen in either of two ways. The first is as follows.

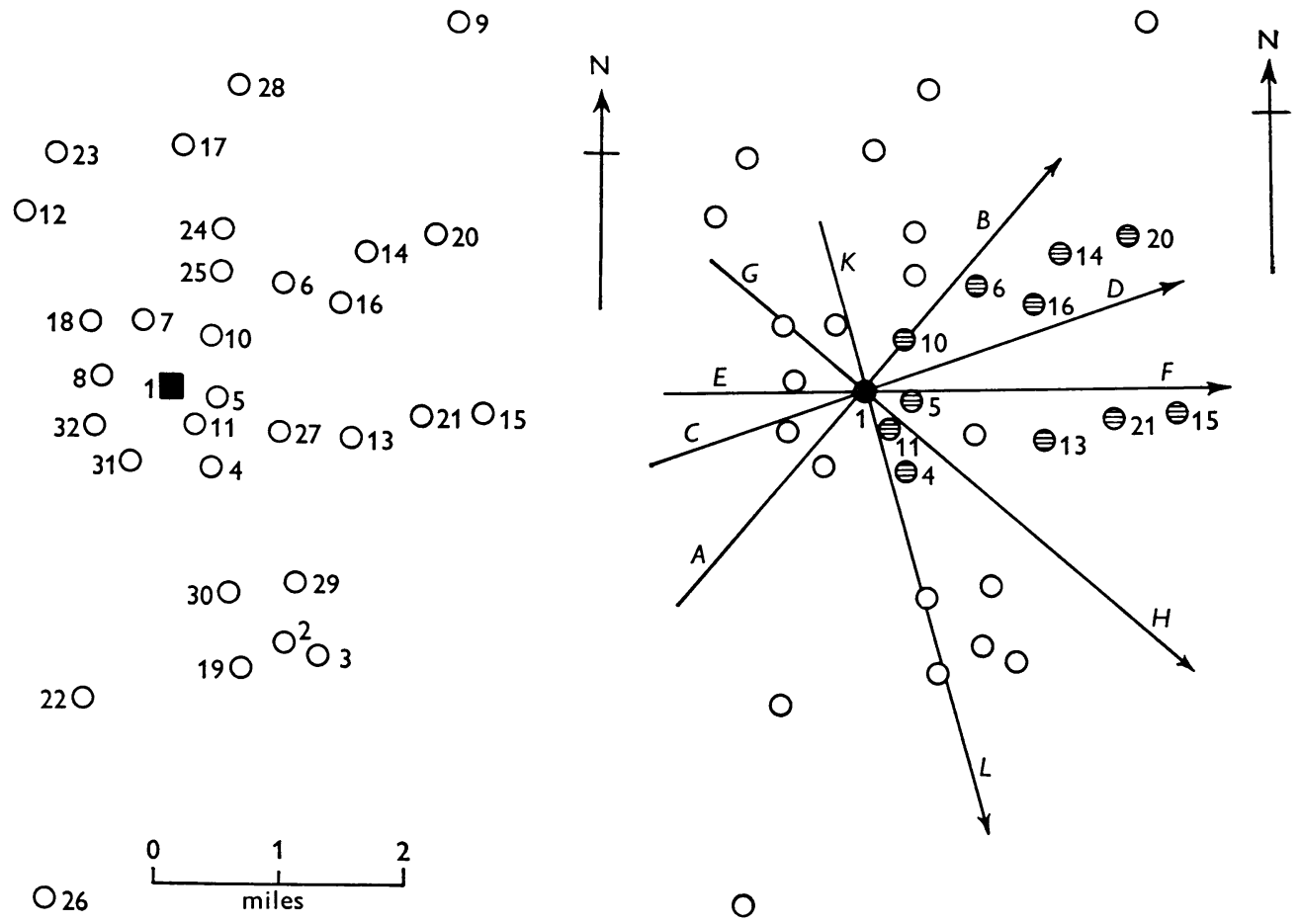

Fig. 1

Fig. 2

Fig. 1. The farms affected in the Worcestershire outbreak. The numbers indicate the order in which infection appeared. Farm 9, 16 miles distant at Kidderminster, was infected by means other than by the wind and is not considered further in the text.

Fig. 2. Farms possibly infected on 15. xi. 67. from farm 1 (focus of infection). Farm 1 is shaded black. The infected farms are shown by cross-hatching.

Virus particles are expelled into the air on the breath or saliva of infected animals or from the animals' chests which are squeezed when the carcases are dragged by the tractors, or from blisters ruptured when the dragging chains are applied, or attached to dust particles when the excavators dig the burial pits; the wind could lift the virus particles and carry them along with it. Some of the particles could be brushed off on any obstacle in the path of the wind (haystacks, dutch barns, sheds, trees, cattle); some on to crops such as kale or grass, particularly if they are wet. 
There is every possibility that this happened, and the accompanying diagrams show the wind direction throughout the Worcestershire episode.

On 15 November (Fig. 2) a light breeze (1-3 knots)* came from the south-west virtually all day, veering between lines $A B$ and $C D$. At $21.00 \mathrm{hr}$. it changed to a westerly direction along line $E F$ (strength about $10 \mathrm{knots}$ ). Then from 21.00 to $24.00 \mathrm{hr}$. it blew from the north-west between lines $G H$ and $K L$ (strength slightly over $10 \mathrm{knots}$ ). Thus farms lying in the path of the wind were in danger of being infected about the same time on the 15th. As it so happened farms down-wind

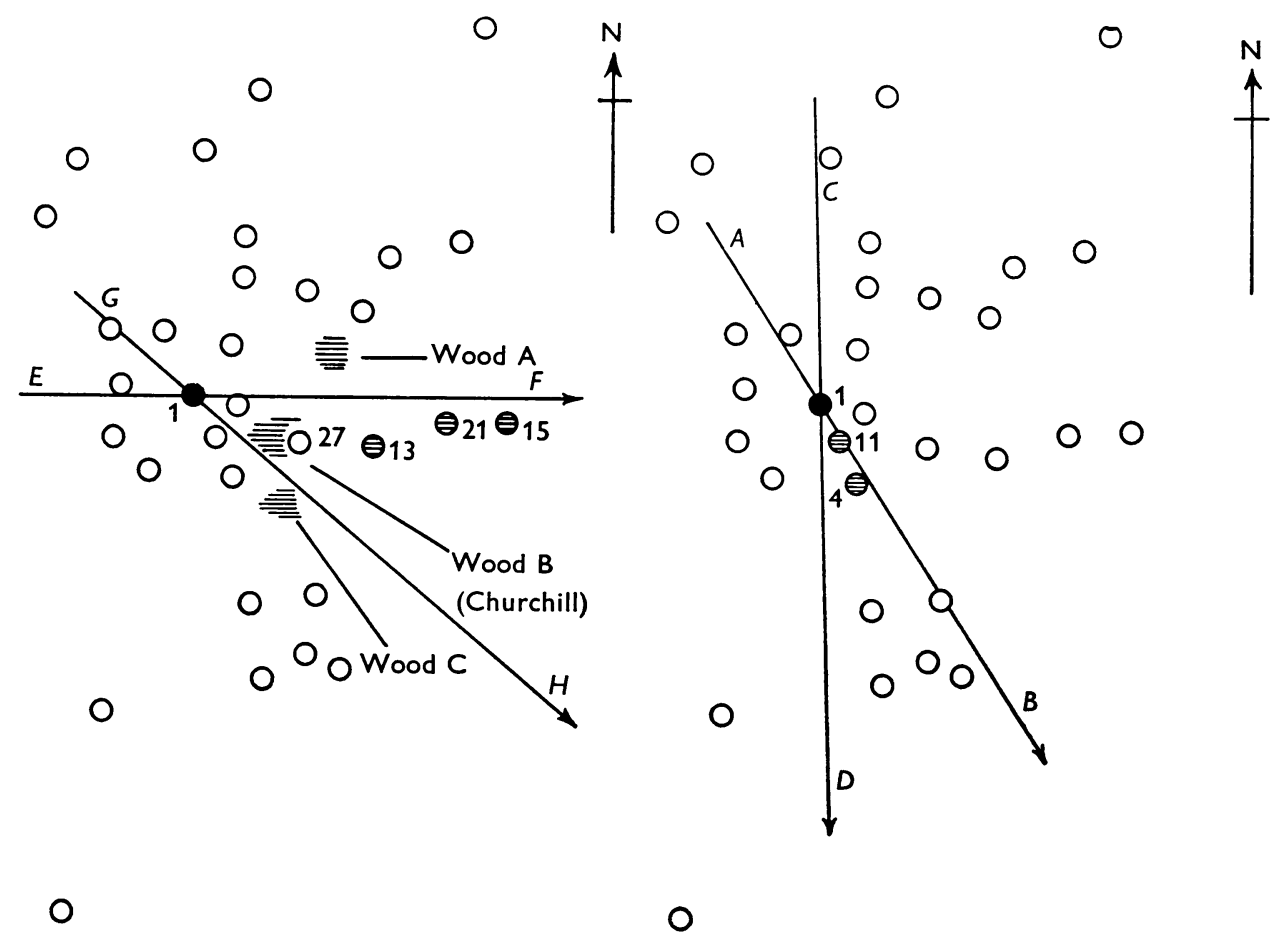

Fig. 3

Fig. 4

Fig. 3. Protection of farm 27 by Churchill Wood. Farms 13, 15, 21, unprotected, became infected from farm 1.

Fig. 4. Wind direction on 16. xi. 67. Farms 4 and 11 infected from 1.

from the focus of infection and lying in paths roughly half a mile wide running north-east, east and south-east, were infected. Their position is indicated in Fig. 2. Disease broke out on these farms between 20 and 25 November. $\dagger$ The farms nearest the focus showed the disease first, those further away showed it later. There was one notable exception. Considerable interest arose because one farm which lay in the path of the wind was not infected at the time with the others although it was one of those nearest the focus (Fig. 3). It is screened on its west and north flanks

* Beaufort scale equivalent given in Appendix I.

$\dagger$ A possible explanation of the apparent lengthening of the incubation period is given in the Discussion. 
by a belt of trees, Churchill Wood, which is at least 300 yards wide. The trees are 40-50 ft. high. The assumption was that infection did not reach the farm buildings (the cows had been brought in immediately word was received of the outbreak) because they lay close in under the lee of the trees. The farm was actually infected much later when the wind was blowing in the reverse direction and it was presumed infection was carried to it from the neighbouring farm to the east (Fig. 7).

On 16 November the virus was probably being dispersed in greatest quantity from farm 1. A light breeze came from the north-west and north (strength

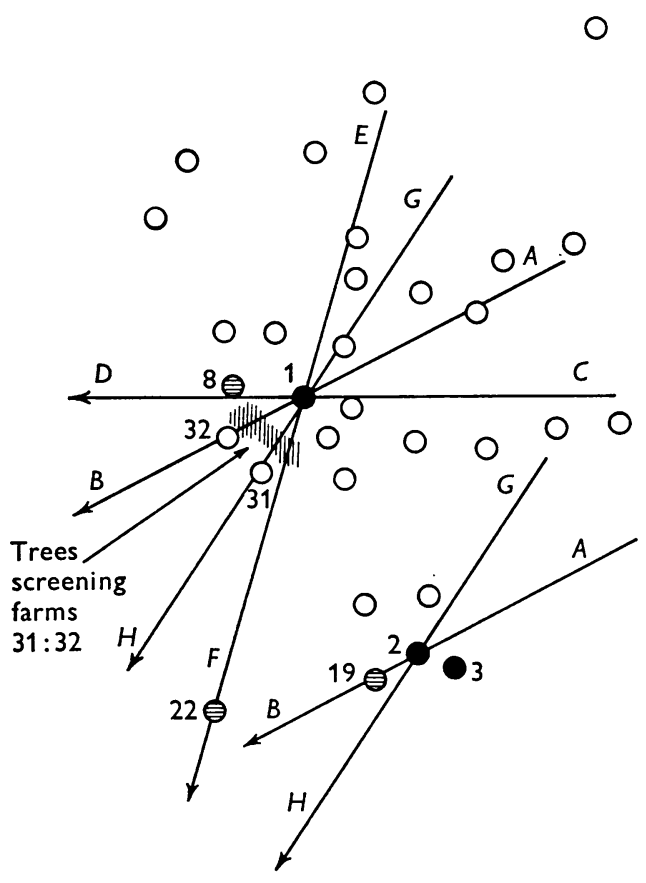

$\theta 26$

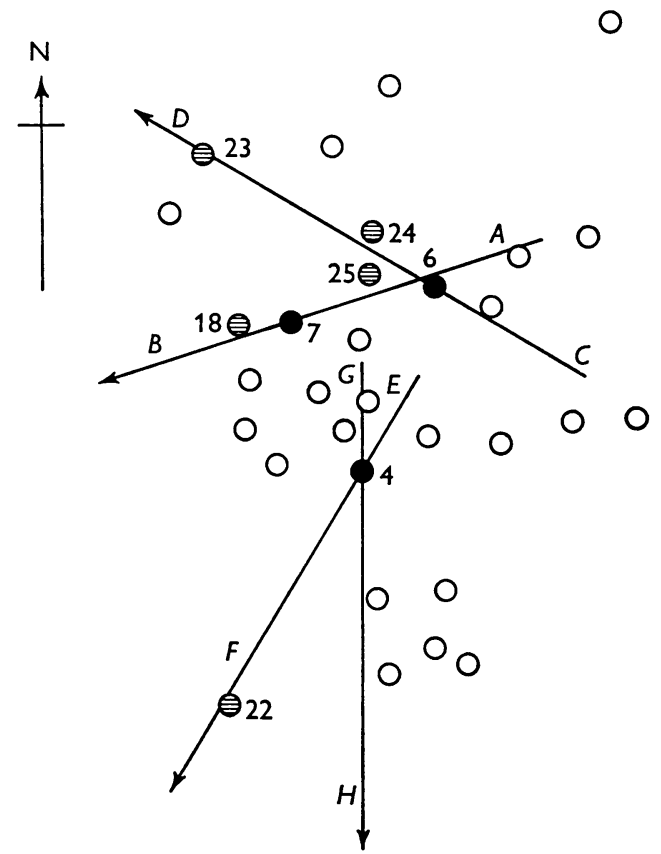

O

Fig. 5

Fig. 6

Fig. 5. Wind direction on 17. xi. 67, 18. xi. 67 and 19. xi. 67. Farm 8 infected from 1 , farm 19 infected from 2, farm 22 infected from 1, farm 26 infected from 2 , farms 32 and 31 protected by trees.

Fig. 6. Wind direction on 20. xi. 67, 21. xi. 67 and 22. xi. 67. Farm 22 infected from 4, farm 18 infected from 7, farm 24 infected from 6, farm 25 probably infected from 6 , farm 23 also infected from 6.

1-6 knots) along a line $A B-C D$ from 00.01 to $17.00 \mathrm{hr}$. (Fig. 4). From then to $24.00 \mathrm{hr}$. it was completely calm. The farms lying in the path of the wind were subjected to a second day's attack by virus particles.

On 17 November the morning was calm from 00.01 to $11.00 \mathrm{hr}$. From 11.00 to $17.00 \mathrm{hr}$. a light breeze (strength 1-6 knots) blew along lines $A B-C D$ (Fig. 5). From 17.00 to $20.00 \mathrm{hr}$. the breeze lay in the north-east (line $E F-G H$ : strength 1-6 knots). In the calm periods on both 16 and 17 November a heavy dew fell. The disease broke out on two farms ( 8 and 22) on 22 and 25 November respectively. 
It seems that farms 31 and 32 , lying directly in the path of the wind $A B-G H$, ought to have been infected from farm 1 , less than 1 mile away. It is likely that they were protected, as in the case of farm 27, by trees (Fig. 5). There is a thick belt of tall trees on both sides of Spetchley road giving ample protection from the north. Farms 31 and 32 were infected later from the south. There are no trees on their southern aspects.

A second source of infection now appears. The disease broke out on the second of the three pig farms (Farm 2) on 17 November (Fig. 5). The farm immediately adjacent to the west, 19, could have been infected on this or the following day. On the pig farm where the disease had originally broken out all the stock had been slaughtered and buried by nightfall on 17 November and total disinfection of the premises had begun.

On 18 and 19 November a light breeze came mainly from the north-east (line $G H$ ). The third of the three pig farms (farm 3) showed infection on the 18th.

The situation on 20,21 and 22 November is shown in Fig. 6. A change now appeared because farms infected from the original focus began to show infection themselves and virus was dispersed from these new sources. From soon after 24.00 until $11.00 \mathrm{hr}$. on the 20th a light breeze blew (strength 1-6 knots) along line $A B$. Until $20.00 \mathrm{hr}$. it came along $C D$. From 20.00 to $24.00 \mathrm{hr}$. it was along line $E F$ and at $24.00 \mathrm{hr}$. it backed to along line $G H$. On the 21 st the breeze blew all day along line $E F-A B$. On the 22nd there was little change. Farm 18 was probably infected from 7; farm 22 from 4 ; farms 24 and 25 from 6.

On the 23rd a light breeze came from south-east and south along lines $A B-C D$, $E F-G H$. (Fig. 7). Farm 23 was probably infected from farm 6 and farms 24 and 25 subjected to a second day's attack from 6 . The cattle were inside in farms 23 and 24 and this fact may have resulted in some slight delay in the infection reaching them. Farm 27, originally protected by the trees on its west flank, was now possibly infected from the farm immediately to the east. Its east flank was open and unprotected. The fact of the cattle being inside also offered no protection.

From 24 November to 2 December the wind came almost continuously from the south with slight variations to the south-east or to the south-west (Fig. 8). Five farms were probably infected now. One of these, 31, (Figs. 1, 8) was probably subjected to a constant barrage of virus particles from farm 22 immediately to the south of it since farm 22 was a source of heavy infection for various reasons* from 25 to 29 November. Farm 31, in addition to pedigree cattle, held a valuable herd of some 300 deer. These were watched daily by veterinarians with binoculars. One lame animal was penned and slaughtered for a check. It was uninfected. The herd of deer escaped $\dagger$ but the cattle on the farm showed heavy infection on 1 and 2 December.

* The veterinarians thought that the disease had been present for $48 \mathrm{hr}$. before it was reported, the infection was so advanced and widespread. In addition the slaughterers stopped work for a whole day because of some disagreement.

$\dagger$ There were many herds of deer exposed to infection in various parts of the country. Surveillance was thorough and not one animal was found to have caught the disease. I am informed that samples of blood did not show antibody formation. It can be assumed therefore that subclinical infection did not take place and the answer is simply that deer in this country are not susceptible. 
Farms 30 and 29 were probably infected from farm 19. The owner of farm 30 was standing on raised ground listening to the sound of the excavators digging the burial pits on farm 19; the wind, he said, was blowing from the south, directly from farm 19 to his. He went in and told his wife that nothing now could save his stock. Six days later infection broke out among his sheep.

The last farm to be infected, 32 (Figs. 1, 8), could have received the virus from the neighbouring farm on 1 or 2 December. The disease showed itself on 6 December.

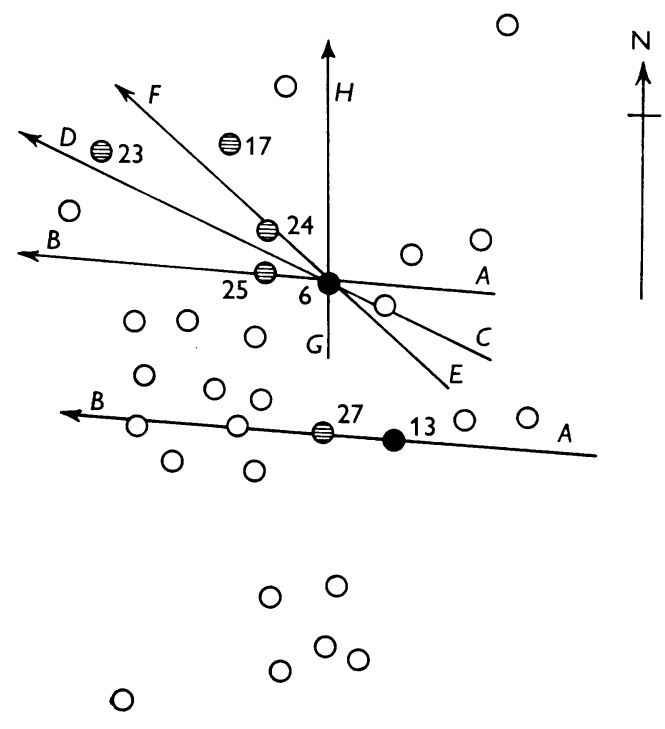

O

Fig. 7

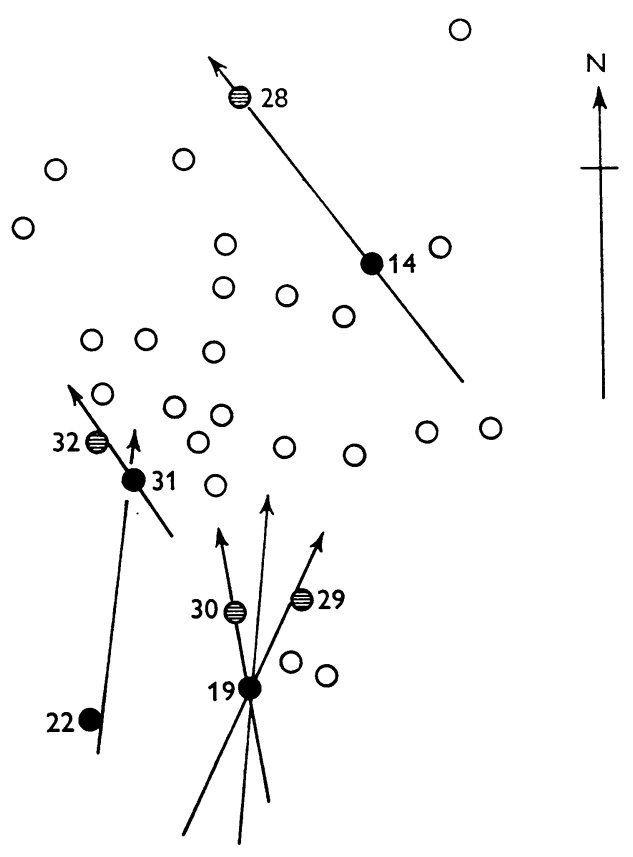

O

Fig. 8

Fig. 7. Wind direction on 23. xi. 67. Farm 27, hitherto protected by Churchill Wood from the west and south-west, is now infected by an east wind from farm 13. Farms 24 and 25 still infected from 6, farm 23 infected from 6, farm 17 also infected from 6 .

Fig. 8. Wind direction between 24. xi. 67 and 2. xii. 67. Farms 29 and 30 infected from 19, farm 28 infected from 14, farm 31 infected from 22, farm 32 infected from 31.

The second way in which virus particles may be carried is rather more complicated and the effect of turbulence must be considered. Even in a gentle breeze (1-6 knots) there is an area of turbulence extending upwards from ground level to as high as $500 \mathrm{ft}$. Thus as virus is being dispersed the particles may be eddying up and down on the waves of turbulence while at the same time the whole mass moves along in the direction of the wind. While some particles in the lower reaches of the turbulence will be brushed off on features on the ground, the majority will remain aloft until brought down by light rain or settling of the dust. The particles themselves will fall during a period of complete calm. 
Thus a plume down-wind of the original focus and perhaps extended for a distance of up to 3 miles could have been created by the breeze and turbulence on 15 and 16 November. From $17.00 \mathrm{hr}$. on the 16 th until 11.00 on the 17 th there was complete calm, with slight fog and a heavy dew. If it is believed that virus particles would be deposited during the period of calm then virtually all the farms to the east of the infected focus would have been in an area of fairly heavy concentration of virus. When the wind changed on 17 November and lay in the north-east and east the plume would tend to move west and west-south-west. When secondary outbreaks took place on the farms infected from the original focus the concurrence of light breezes, turbulence and calm would complete infection of the whole area.

\section{DISCUSSION}

For a long time there has been a feeling among veterinarians in this country that the virus of foot-and-mouth disease can be carried on the wind; in fact, on occasions the circumstantial evidence has been so strong that they have been obliged to accept this as the only way in which the disease could have spread. During outbreaks they have always advised farmers to get the stock under cover. Saliva from infected animals has been observed to be carried off by the wind and it has been proved experimentally that for a short distance at any rate the virus of foot-andmouth disease can be carried through the air (Gowers Report, para 23). In this outbreak the phenomenon of saliva being blown off into the air was actually observed and the veterinarian who first saw it summoned his colleagues from the control point to watch. The animal was a young bullock which had been left out in a field on farm 29 (Fig. 1) near a road. From the road it was quite easy to see the wisps of saliva being borne off in the breeze for some distance.

However, when discussing the possibility of wind-borne spread of virus various climatic factors have to be considered. These are sunlight, rain, and calm. If virus is carried up by the wind, turbulence may take it to a considerable height; at the same time particles carried along near the ground may be brushed off on obstacles in the path of the wind. If there is strong sunlight or if it is a bright day the ultraviolet light will kill the virus in a matter of hours if not in minutes. A good deal will depend on how much mucus surrounds the virus or how much dust is attached to it. Therefore if the weather is bright and sunny much virus will not be carried along on the wind. However, if the wind is very strong or gusty some virus may be carried for considerable distances before the sunlight has had time to kill it.

The next factor is rain. This may have two effects. If the rain is light then it will help to bring the virus down out of the atmosphere and so on buildings, cowsheds, haystacks, fields and animals. Rain does no harm to a virus. If the rain is heavy, however, and if there is a lasting downpour then it is likely that all the virus in the air will be washed down into the ground or be carried away in ditches and gutters.

The third factor is calm. When the air is quite still virus particles surrounded by mucus or attached to dust may descend by their own weight.

Therefore when deliberating whether virus could have spread from the original focus, farm 1, to the surrounding farms, not only must the distance at which the 
farms lie be taken into account but also any obstacle in the path of the wind, such as hills and woods. The direction and strength of the wind in the late afternoons, evenings and nights, the amount and type of rainfall during the period under review and the occurrence of any calm periods must be considered.

The incubation period also is important. This appeared to have been 5-6 days judging by the time the first signs of the disease took to appear on farm 1 after the arrival of the infected milk. In fact, veterinary officers agreed that the incubation period throughout the country was 5-6 days, and this was also the incubation period for the disease on those farms immediately adjacent to farm 1 .

When spread of virus would have been at its maximum from the original focus (farm 1, Fig. 1), i.e. on the 15th, 16th and 17th, the prevailing wind for the first two of these days was from the west and on the third day from the north-west. On the 15 th there was very little sunshine $(0 \cdot 8 \mathrm{hr}$. in fact $)$; on the $16 \mathrm{th} 3 \mathrm{hr}$., on the 17 th none. As regards rainfall, on the 15 th there was very little $(2 \cdot 1 \mathrm{~mm})$, on the 16 th there was even less, and on the 17th none at all. Conditions therefore were suitable for the carriage of virus on the 15th; the very light rain would have helped to bring it down. On the $16 \mathrm{th}$, however, the $3 \mathrm{hr}$. of sunshine might have killed some of the virus, although with the November sun not more than $20^{\circ}$ above the horizon at noon the absorption of ultraviolet light by the atmosphere must have been considerable, and the effect of the light on the virus might therefore have been negligible. On the 17th virus would have survived in the air, but there was no rain to bring it down. There was a breeze on the night of the 15 th and from $17.00 \mathrm{hr}$. on the 16th until $11.00 \mathrm{hr}$. on the morning of the 17th there was a complete calm. The wind strength throughout these 3 days apart from the period of calm was light to moderate (1-10 knots), i.e. a breeze sufficiently strong to have been felt on the face and at times strong enough to lift and carry dust. Atmospheric conditions therefore were suitable for the wind-borne spread of virus.

As it happened, farms to the north-east, and south-east were affected. Two farms showed the disease on the $20 \mathrm{th}$, indicating an incubation period of 5 days if infection took place on the 15th, two on the 21 st giving an incubation of 6 or 5 days depending on whether they were infected on the 15th or 16th, and the remainder, mostly the more distant farms, showed the disease on the 23rd, 24th and 25th. Why was the onset of the disease delayed on the more distant farms? The answer may lie in differences in concentration of virus. The concentration of virus over the distant farms was probably very light and this simply delayed contact with it. Another explanation may be that on farm 21 all the cattle were inside and the virus took longer to reach them, while on farms 13 and 15 most of the animals were inside and the remainder widely separated in the fields. This, together with the light concentration, would also tend to delay contact with the virus. As regards farm 22 where the incubation period appeared to be 7-8 days the veterinary officers consider that because the infection was widespread and heavy when confirmed it could have been present for $48 \mathrm{hr}$. before being reported. The limit of infection was about 3 miles. Farms beyond this were not affected.

On the diagrams the radial direction of spread following the path of the wind on 
the 15th, 16th and 17th is striking. It is difficult to avoid the impression that virus was carried on the prevailing winds.

The theory of wind spread is also supported by what happened to farm 27 (Figs. 2, 3). This farm lay in the direct path of the wind on the 15th but it escaped infection, although farms to the east, west and south were infected. It seems that it was protected on its west flank by Churchill Wood, a thick belt of tall trees (40/50 ft.) 300 yards wide. The ground rises slightly here, bringing the tops of the trees to approximately $100 \mathrm{ft}$. above the level of farm 1 . Thus either the virus was caught in the tree belt or, if turbulence was taking the virus up over trees, the farm buildings were protected from subsequent fall-out of virus by being under the lee of the trees. At any rate the farm escaped infection at this time. So did other farms to the north-east and south-east which were possibly protected by wood A and wood C (Fig. 3). It will be obvious how the westerly breeze would have been able to pass between woods A and B and so infect farms 13, 21 and 15. (Figs. 2, 3).

As it so happened, the disease broke out on farm 27 on 30 November 6 days after it was confirmed in cattle of farm 13 . On the $23 \mathrm{rd}$ and 24 th the wind came from the east, which explains how farm 27 could have been infected from farm 13 (Fig. 7). Thus there is strong circumstantial evidence that the farms to the north-east, east and south-east of farm 1 were infected by wind-carriage of virus in the early part of the Spetchley outbreak.

The remainder of the outbreak may be split into four periods: from 17 to 19 November; from 20 to 22 November; 23 November; and from 24 November to 2 December. As infection appeared on other farms, each in turn became a focus from which further spread was possible. It is true that there was a good deal of sunshine. However, on the days that the sun shone the wind lay in the same direction during the previous night and the same evening and night. It is also true that the dry spell continued for the most part, but slight amounts of rain fell on 25 November and from the 27 th to the 30 th. However, there were sufficient periods of calm to have allowed for deposition of virus.

Two farms, nos. 7 and 12 (Fig. 1) showed the disease on the 20th and 23rd respectively. These lay to the north-west of the original focus and direct infection by wind carriage cannot be postulated if a 5- or 6-day incubation period is accepted since the wind did not lie in this direction during the required time. It is not known how these farms became infected; a possible explanation is by westward movement of a plume (p. 27).

An interesting feature that emerged from the study was that when cattle had been brought inside they did not seem to be any better protected than those that remained outside. All that happened was that the spread of infection was delayed by 1 or 2 days. In nine farms the cattle had been brought inside, well before the outbreak began in two, and immediately on receiving word that the outbreak had begun in seven. In nineteen farms the animals (cattle or sheep) remained outside during the outbreak. The only difference between the two groups lay in the fact that infection took longer to reach those inside.

Although one farmer expeditiously brought his cattle into their sheds within an hour or so of hearing about the outbreak on farm 1 he continued to feed them on 
cut kale from the field in which they had been grazing. The kale crop was in the direct path of the wind and he obviously could not have chosen a surer way of infecting his cattle with the virus.

The position of sheds and byres or the way in which they faced seemed to matter little. Although in some instances the doors of the sheds faced away from the prevailing wind there were ventilation openings in the shed walls. Short of hermetically sealing cow sheds or pig pens it is difficult to see how bringing cattle or pigs inside can do more than delay the onset of infection. This is especially so when bringing them in means that they have to be fed with hay which is likely to have been stored in Dutch barns. Dutch barns offer little protection against virus carried on the wind.

It seems feasible to make deductions about the range of carriage of the virus on the wind. On the 15th, 16th and 17th when spread from farm 1 was at its height, farms beyond 3 miles from the focus were not affected. In fact at no time during the outbreak was any farm which lay more than 3 miles from any focus affected. Since the wind was never stronger than 10 knots at any time during the outbreak it seems reasonable to suppose that a 10-knot wind will carry the virus up to 3 miles. Further, infection seemed solid on farms up to 1 or $1 \frac{1}{2}$ miles distant from any focus, and less so, i.e. the virus was sparsely deposited, on farms at a distance of $1 \frac{1}{2}-3$ miles. I postulate this because the disease took longer to appear on the more distant farms and it is possible that because the virus was sparsely distributed it took a little longer for the stock to come in contact with it.

This, if it is a correct interpretation, might be a useful guide to veterinarians during the course of future outbreaks. It is for consideration whether it would be worth while, when faced with a down-wind spread, ordering slaughter on all farms in the path of the wind for a distance far enough to ensure that the disease is stamped out quickly and completely.

\section{Animals \\ Other possible methods of spread}

Spread by foxes and other vermin was considered and discussed at length with farmers. A fox can pick up virus on his paws and coat when running through infected kale or grass. He might then infect other fields, but it is against his habits to enter cowsheds or pigpens. The farmers told me about any fox-runs and foxhides on their land; on the whole they agreed that it would have been a very unusual coincidence if a fox or foxes could have accounted for all the disease in the Spetchley area. The manager of the pig farm where it all began had not seen a fox cross his fields before the outbreak or enter his pig pens. Other vermin, e.g. rats, were not thought by the farmers to be implicated. Rats usually remain close to a farm and do not leave. The only time rats were seen to move about was when farms were being dis-infected; there was no evidence however of their migrating to other farms. 


\section{Birds}

Several farmers mentioned sparrows; it seemed they were numerous on some farms. Farmers agreed that sparrows remained near one farm and did not tend to move about in flocks from farm to farm. Only one farmer mentioned starlings. There was a flock which roosted at night in a wood near his farm and fed in his fields during the day. He did not think they would have gone to other farms although he had no proof of this. Pigeons were not thought to be implicated in any way since they did not come into pig pens or cowsheds. Pheasants, on the other hand, were blamed and one farmer described how when he was going round his fields he came on a bullock which obviously had the disease, the saliva dripping from its mouth having made a pool on the ground. As he approached, two pheasants got up which had, he said, been feeding on the saliva. Several farmers mentioned the possibility of the disease having been spread by pheasants; the Spetchley area is noted for them. However, in my view spread by these birds would have resulted in a very haphazard distribution not at all like that which was actually observed.

\section{Persons}

From the earliest days of the outbreak farmers in the neighbourhood of the affected farm observed the strictest precautions to prevent the disease from being brought to their farms by persons. Access gates were closed except one and a disinfectant 'pad' was laid across the entrance. Vehicles were not allowed to enter; domestic supplies and mail were taken at the gate; the farmer and his wife did not go out. If they were obliged to go out they disinfected their car. The children were kept at home. Workers on the farms disinfected their boots and changed their clothes where possible before going home in the evening. As more farms became infected the precautions became more strict. I went into the possibility of the virus being carried on persons or cars very thoroughly and I could find no common factor. It did not seem that transfer of virus on persons was playing any part in the outbreak.

\section{Transfer by vehicles}

The milk was collected from a large number of farms in the area by tanker. At one stage it was thought that the tankers were possibly transferring the disease from farm to farm. Investigation of the routes the tankers followed showed that this was not possible. In each case the route was the reverse of that taken by the disease. However, some farmers remained suspicious of the tankers, especially of the vacuum artificially created before taking in the milk. Some farms took in loads of animal feedingstuffs during the outbreak, but this was virtually always supplied in bags and had come from a source outside the infected area. Although two farms in another part of Worcestershire, unconnected with Spetchley, were infected from a haulier's lorry I did not find any evidence that carriage of virus on vehicles or on vehicle wheels played any part in the Spetchley outbreak; it seems a pity, however that 'progress' has done away with the safeguard of leaving the churns on a platform at the farm gate for collection (Gowers Report, para 170). 


\section{Transfer by veterinarians}

In the Gowers Report, app. V, approximately ten instances of the 1951-2 outbreak where infection could have been brought to farms by veterinarians are described. Farmers had mixed views about allowing veterinarians to come into their premises to inspect stock; one whose farm escaped although there was infection virtually all around flatly refused to allow a young veterinarian to come into his premises because he had just come from a farm where the disease had been confirmed. Another farmer did allow him to come in and inspect- the disease broke out in the farm 5 days later. However, this was the only occasion where a visit by a veterinarian who had been involved in infection was followed by the disease 5 or 6 days later.

\section{SUMMARY}

1. Foot-and-mouth disease broke out on three pig farms of the Spetchley area of Worcestershire after the virus had been carried to them in skimmed milk.

2. A study of the natural features of the area and of the climatic conditions during the outbreak show that the wind could have carried the virus from one or other of these three to twenty-six others of the total thirty-two farms infected.

3. Bringing the cattle from the fields and keeping them in their sheds offered no protection. Nine farmers did so but the only effect was that the onset of infection was delayed for a day or so.

4. The direction in which cow-sheds faced likewise made no difference. Openings in the walls for ventilation obviously allowed virus to be carried inside.

Mr J. S. Needham, M.R.C.V.S., first showed me that the wind could have been responsible for the spread of the disease in the Spetchley outbreak. I am glad to be able, after my study, to support his view. I am indebted to Mr V. Harris, Officerin-charge, R.A.F. Meteorological Station, Pershore, Worcestershire, for the climatic details.

\section{REFERENCE}

Report of the Departmental Committee on Foot-and-mouth Disease 1952-54 (The Gowers Report). H.M.S.O. 1960.

\section{APPENDIX 1}

Wind directions and force Spetchley/Pershore area of Worcestershire from 14 November to 2 December 1967

14. xi. 67 Few light westerlies, otherwise $210^{\circ} / 260^{\circ}$ light to moderate all day.

15. xi. $6700.01-20.00 \mathrm{hr}$. $230^{\circ} / 250^{\circ}$ light to moderate. At $21.00 \mathrm{hr}$. $270^{\circ}$ moderate. $21.00-24.00 \mathrm{hr} .310^{\circ} / 340^{\circ}$ moderate.

16. xi. $6700.01-17.00 \mathrm{hr} .340^{\circ} / 360^{\circ}$ light occasionally moderate. Very variable. 17.00 $24.00 \mathrm{hr}$. calm.

17. xi. $6700.01-11.00 \mathrm{hr}$. calm. $11.00-17.00 \mathrm{hr} .070^{\circ} / 100^{\circ}$ light. $17.00-20.00 \mathrm{hr} .020^{\circ} / 060^{\circ}$ light. $20.00-24.00 \mathrm{hr}$. calm.

18. xi. $6700.01-12.00 \mathrm{hr} .010^{\circ} / 030^{\circ}$ light. $12.00-21.00 \mathrm{hr} .020 / 070^{\circ}$ light. $21.00-24.00 \mathrm{hr}$. $090^{\circ} / 120^{\circ}$ light.

19. xi. $67 \quad 00.01-24.00 \mathrm{hr} .040^{\circ} / 100^{\circ}$ light.

20. xi. $6700.01-11.00 \mathrm{hr} .080^{\circ} / 110^{\circ}$ light. $11.00-20.00 \mathrm{hr} .040^{\circ} / 070^{\circ}$ light. $20.00-24.00 \mathrm{hr}$. $040^{\circ} / 360^{\circ}$ light. 
21. xi. $67 \quad 00.01-24.00 \mathrm{hr} .040^{\circ} / 070^{\circ}$ light.

22. xi. $67 \quad 00.01-24.00 \mathrm{hr} .060^{\circ} / 100^{\circ}$ light.

23. xi. $6700.01-09.00 \mathrm{hr}$. $100^{\circ} / 130^{\circ}$ light. $09.00-12.00 \mathrm{hr} .150^{\circ} / 180^{\circ}$ light. $12.00-15.00 \mathrm{hr}$. calm. $12.00-24.00 \mathrm{hr} .120^{\circ} / 170^{\circ}$ light.

24. xi. $6700.01-12.00 \mathrm{hr}$. $130^{\circ} / 180^{\circ}$ light. $12.00-18 \cdot 00 \mathrm{hr}$. calm. $18 \cdot 00-24 \cdot 00 \mathrm{hr} .220^{\circ} / 240^{\circ}$ light.

25. xi. $6700.01-18.00 \mathrm{hr} .020^{\circ} / 070^{\circ}$ light after early calm. $08.00 \mathrm{hr} .220^{\circ} / 250^{\circ}$ light.

26. xi. $6700.01-07.00 \mathrm{hr} .220^{\circ} / 250^{\circ}$ light. $07.00-11.00 \mathrm{hr}$. calm. $11.00-13.00 \mathrm{hr} .260^{\circ}$ light. 13.00-17.00 hr. $310^{\circ}$ light $17.00-24.00 \mathrm{hr} .220^{\circ} / 250^{\circ}$ light.

27. xi. $67 \quad 00.01-24.00 \mathrm{hr} .210^{\circ} / 230^{\circ}$ light.

28. xi. $6700.01-10.00 \mathrm{hr} .230^{\circ}$ light to moderate. $10.00-24.00 \mathrm{hr} .270^{\circ} / 280^{\circ}$ moderate.

29. xi. $6700.01-11.00 \mathrm{hr} .260^{\circ} / 290^{\circ}$ light to moderate. $11.00-17.00 \mathrm{hr} .280^{\circ} / 310^{\circ}$ moderate. 17.00-20.00 hr. $270^{\circ}$ light. $20.00-24.00 \mathrm{hr} .200^{\circ} / 220^{\circ}$ light.

30. xi. $67 \quad 00.01-24.00 \mathrm{hr} .200^{\circ} / 230^{\circ}$ light.

1. xii. $6700.01-10.00 \mathrm{hr} .260^{\circ}$ light. $10.00-19.00 \mathrm{hr} .360^{\circ} / 020^{\circ}$ light. $19.00-24.00 \mathrm{hr}$. calm.

2. xii. $6700.01-21.00 \mathrm{hr}$. calm. $21.00-24.00 \mathrm{hr} .260^{\circ} / 280^{\circ}$ light.

\section{Interpretation}

Calm = calm smoke rises vertically. Light air $=1-3$ knots (smoke drift can be seen). Light breeze $=4-6$ knots (wind felt on face, wind vane is moved, leaves rustle). Gentle breeze = 7-10 knots (leaves and small twigs in constant motion, a light flag is extended). Moderate breeze $=11-16$ knots (dust and loose paper raised).

\section{APPENDIX 2}

Rainfall in the Spetchley/Pershore area of Worcestershire from 14 November to 2 December 1967

\begin{tabular}{|c|c|c|c|c|c|}
\hline Date & $\begin{array}{c}\text { Rainfall } \\
\text { (mm.) }\end{array}$ & $\begin{array}{c}\text { Duration } \\
\text { (hr.) }\end{array}$ & Date & $\begin{array}{c}\text { Rainfall } \\
\text { (mm.) }\end{array}$ & $\begin{array}{c}\text { Duration } \\
(\mathrm{hr} .)\end{array}$ \\
\hline 14. xi. 67 & $1 \cdot 9$ & $2 \cdot 1$ & 24. xi. 67 & - & 一 \\
\hline 15. xi. 67 & $2 \cdot 1$ & $1 \cdot 8$ & 25. xi. 67 & 0.5 & $1 \cdot 0$ \\
\hline 16. xi. 67 & Tr. & - & 26. xi. 67 & - & - \\
\hline 17. xi. 67 & - & - & 27. xi. 67 & $1 \cdot 1$ & 1.9 \\
\hline 18. xi. 67 & - & - & 28. xi. 67 & $1 \cdot 2$ & $1 \cdot 2$ \\
\hline 19. xi. 67 & - & - & 29. xi. 67 & Tr. & - \\
\hline 20. xi. 67 & Tr. & - & 30. xi. 67 & 0.5 & $1 \cdot 3$ \\
\hline 21. xi. 67 & - & 一 & 1. xii. 67 & - & - \\
\hline 22. xi. 67 & - & - & 2. xii. 67 & Tr. & - \\
\hline 23. xi. 67 & 一 & - & & & \\
\hline
\end{tabular}

APPENDIX 3

Daily hours of sunlight in Spetchley/Pershore area of Worcestershire from 14 November to 2 December, 1967

$\begin{array}{cccc}\text { Date } & \begin{array}{c}\text { Sunlight } \\ \text { (hr.) }\end{array} & \text { Date } & \begin{array}{c}\text { Sunlight } \\ \text { (hr.) }\end{array} \\ \text { 14. xi. } 67 & 3 \cdot 7 & 24 . \text { xi. } 67 & 0 \cdot 8 \\ \text { 15. xi. } 67 & 0 \cdot 8 & 25 . x i .67 & 0 \cdot 8 \\ \text { 16. xi. } 67 & 2 \cdot 9 & 26 . x i .67 & 1 \cdot 0 \\ \text { 17. xi. } 67 & \text { Nil } & 27 . x i .67 & \text { Nil } \\ \text { 18. xi. } 67 & 0 \cdot 6 & 28 . x i .67 & \text { Nil } \\ \text { 19. xi. } 67 & 0 \cdot 2 & 29 . x i .67 & \text { Nil } \\ \text { 20. xi. } 67 & 4 \cdot 9 & 30 . x i .67 & \text { Nil } \\ \text { 21. xi. } 67 & \text { Nil } & 1 . x i i .67 & \text { Nil } \\ \text { 22. xi. } 67 & 7 \cdot 1 & 2 . x i i .67 & \text { Nil } \\ \text { 23. xi. } 67 & 3 \cdot 1 & & \end{array}$

